\title{
The Impact of Weight Change During and After Post-Operative Chemotherapy on Breast Cancer Control in Node-Positive Patients Treated With Trimodality Therapy
}

\author{
Joshua Johnson ${ }^{1}$, Bianca Lamb ${ }^{1}$, Andrew Mills ${ }^{1}$, Patricia L Watkins ${ }^{5}$, Vijay Chaudhary ${ }^{3}$, Jayaram Bharadwaj ${ }^{4}$, \\ Tarek A. Dufan ${ }^{2}$ \& John M. Watkins 2,6 \\ ${ }^{1}$ The University of North Dakota School of Medicine and Health Sciences, Southwest Campus, Bismarck, North \\ Dakota, U.S.A. \\ ${ }^{2}$ Bismarck Cancer Center, Bismarck, North Dakota, U.S.A. \\ ${ }^{3}$ Sanford Bismarck Medical Center, Department of Hematology and Oncology, Bismarck, North Dakota, U.S.A. \\ ${ }^{4}$ St. Alexius Medical Center, Department of Hematology and Oncology, Bismarck, North Dakota, U.S.A. \\ ${ }^{5}$ University of Iowa, Carver School of Medicine, Department of Pediatrics, Iowa City, Iowa, U.S.A. \\ ${ }^{6}$ University of Iowa, Carver School of Medicine, Department of Radiation Oncology, Iowa City, Iowa, U.S.A. \\ Correspondence: John M. Watkins, M.D., University of Iowa, Department of Radiation Oncology, 200 Hawkins \\ Drive, Iowa City, Iowa 52242, U.S.A. Tel: 1-319-384-9517. E-mail: john.m.watkins.md@hotmail.com
}

\author{
Received: July 14, 2014 Accepted: August 8, 2014 Online Published: August 18, 2014 \\ doi:10.5539/cco.v3n2p16 URL: http://dx.doi.org/10.5539/cco.v3n2p16
}

\begin{abstract}
Objective: The purpose of this investigation was to determine whether an association exists between post-operative chemotherapy weight change and breast cancer control and survival, specifically within a high-risk population of women with node-positive breast cancer diagnosed and treated in the contemporary setting.
\end{abstract}

Methods: A retrospective investigation with the following eligibility criteria: women who underwent primary surgical therapy for invasive breast cancer, were found to have pathologic evidence of nodal involvement, and were treated with adjuvant chemotherapy and radiation therapy. Demographic, tumor-, and treatment-related data were recorded and analyzed for association with disease control and survival outcomes. The post-operative/pre-chemotherapy weight and BMI served as the baseline comparator for future weight/BMI changes.

Results: From January 2004 through December 2008, 52 patients were identified for inclusion. At a median follow-up of 77.2 months (range 19.9-119.4, with $85 \%$ followed $\geq 5$ years), 8 patients experienced disease recurrence and 7 patients had died (3 with recurrent disease). Analysis of factors associated with study endpoints identified absolute weight and BMI change at 1, 3, and 4 years post-chemotherapy completion as significantly inversely associated with overall survival, but not associated with freedom from failure. Additionally, a statistically significant association between number of lymph nodes involved and freedom from failure was identified.

Conclusion: This investigation did not detect statistically significant associations between weight or BMI change during chemotherapy and disease control or survival within this high-risk population, while the number of lymph nodes involved was directly related to risk of disease failure. Weight change at intervals following chemotherapy completion demonstrated some association with overall survival.

Keywords: breast neoplasms, chemotherapy, BMI, weight change

\section{Introduction}

Breast cancer is a devastating disease with significant individual and societal implications. It is the most commonly diagnosed cancer among females in the United States, and currently accounts for an estimated 230,000 new cases each year (Siegel et al., 2013). Data from Surveillance, Epidemiology, and End Results (SEER) database demonstrates that one in eight women in the U.S. will be diagnosed with the disease in their 
lifetime (SEER, 2011). Mortality from breast cancer is second only to lung cancer, accounting for over 40,000 deaths each year, and breast cancer is the leading cause of cancer death among women 40-49 years of age (Seigel et al, 2013). The five year survival rates include $98 \%$ for localized disease, $84 \%$ for locoregionally advanced disease, and $27 \%$ for metastatic disease (Newman, 2009). The highest rate of breast cancer is observed in Caucasian women, but it is the most common cancer among women for every major ethnic group.

Obesity is a risk factor for the development of new cases of breast cancer and also affects survival in women who already have been diagnosed with breast cancer (Protani et al., 2010). There is a consistently demonstrated correlation between increased risk for breast cancer and increasing hormone levels (estradiol and estrone) (Key et al., 2002). As peripheral conversion of endogenous estrogens occurs predominately in adipose tissue, increases in body weight have been directly associated with circulating estradiol and estrone, which may fuel tumor growth (6); this is felt to account for the association between obesity and increased risk for breast cancer noted above.

Weight gain is a common problem among patients with breast cancer who receive adjuvant (post-operative) chemotherapy (Demark-Wahnefried et al., 1997; Demark-Wahnefried, Winer, \& Rimer, 1993; Ganz et al., 1987; Goodwin et al., 1999; Heasman et al., 1985). This has been a consistent finding since the initial observation made by Dixon et al. (1978). This is especially pronounced in pre-menopausal patients and those who receive multi-agent chemotherapy regimens, with up to $25 \%$ of gaining more than $11 \mathrm{~kg}$ (Demark-Wahnefried et al., 1997; Demark-Wahnefried, Winer, \& Rimer, 1993). Weight gain is undesirable in this population for several reasons including negative effect on quality of life and predisposition to obesity-related disorders (hypertension, diabetes, cardiovascular and gallbladder disease, and orthopedic disorders) (Demark-Wahnefried et al., 2001). In addition, studies have shown that chemotherapy-associated weight gain in pre-menopausal women is directly associated with risk of breast cancer relapse and mortality (Camoriano et al., 1990).

The purpose of the present investigation is to determine the impact of the degree of weight change during chemotherapy on breast cancer control within a high-risk population of pre- and post-menopausal women with node-positive breast cancer who underwent contemporary tri-modality therapy, including surgery, chemotherapy, and radiation therapy.

\section{Method}

\subsection{Patient Selection Criteria}

This retrospective review was approved by the institutional review boards of the participating institutions. Cases were identified from electronic medical record review, with preliminary selection as women diagnosed with breast cancer between January 2004 and December 2008. Eligible patients were those diagnosed with node-positive breast cancer who received primary surgical therapy followed by adjuvant chemotherapy and radiation therapy. Patients were excluded if any of the following were noted: pre-operative chemotherapy or hormonal therapy, male gender, metastatic cancer at diagnosis, insufficient follow-up (less than 12 months post-chemotherapy completion), and node-negative disease.

Between January 2004 and December 2008, 61 patients diagnosed with node-positive breast adenocarcinoma underwent curative-intent surgical resection, chemotherapy, and radiation therapy. Of these, 52 were eligible for inclusion in the present study. Reasons for exclusion were insufficient/missing records (5 patients) and neoadjuvant (pre-operative) chemotherapy or hormone therapy (4 patients).

\subsection{Study Data Collection}

Study data were collected from existing quality assurance databases and electronic medical records and included patient demographics, tumor characteristics (including tumor location and laterality, histology, tumor grade, number of disease foci, number of nodes removed and involved, tumor size, presence/absence of lymphovascular or perineural invasion, hormone receptor status, HER-2 status, surgical margin specifics, clinical and pathologic stage), treatment factors (including surgical procedure performed, radiotherapy and systemic therapy specifics), and outcome variables (including disease control and survival status at last follow-up, interval to last follow-up, interval to disease recurrence, location of initial disease recurrence, recurrence work-up studies performed, and salvage therapy specifics.). Specific to weight change, pre-operative and post-operative (pre-chemotherapy) weights and body mass index (BMI) were recorded, as were post-chemotherapy weights (immediate, 6-month, and annually through 5 years post-chemotherapy). The post-operative/pre-chemotherapy weight served as the baseline comparator for change for future weight and BMI levels.

Patients were generally followed every 3-4 months during the first 1-2 years post-chemotherapy, then every 6 months through 5 years, and annually thereafter. Disease control was measured from the date of definitive 
surgery (lumpectomy or mastectomy) to the date of disease recurrence or last follow-up. Survival was measured from surgery to the date of death or last follow-up.

\subsection{Statistical Analysis}

The Kaplan-Meier method was employed to estimate 5-year freedom from failure (with $95 \%$ confidence intervals, $p$-value $<0.05$ ) for the entire population and subsets. Cox proportional hazards model was used to identify continuous, categorical, and dichotomous variable association with disease control. Analyses were performed using SPSS Version 21 (SPSS, Inc.; Chicago, IL, USA).

\section{Results}

Fifty-two patients were eligible for inclusion in the present study. Patient demographics are outlined in Table 1. Surgical, pathology, and treatment-related data are demonstrated in Table 2.

Table 1. Patient demographics

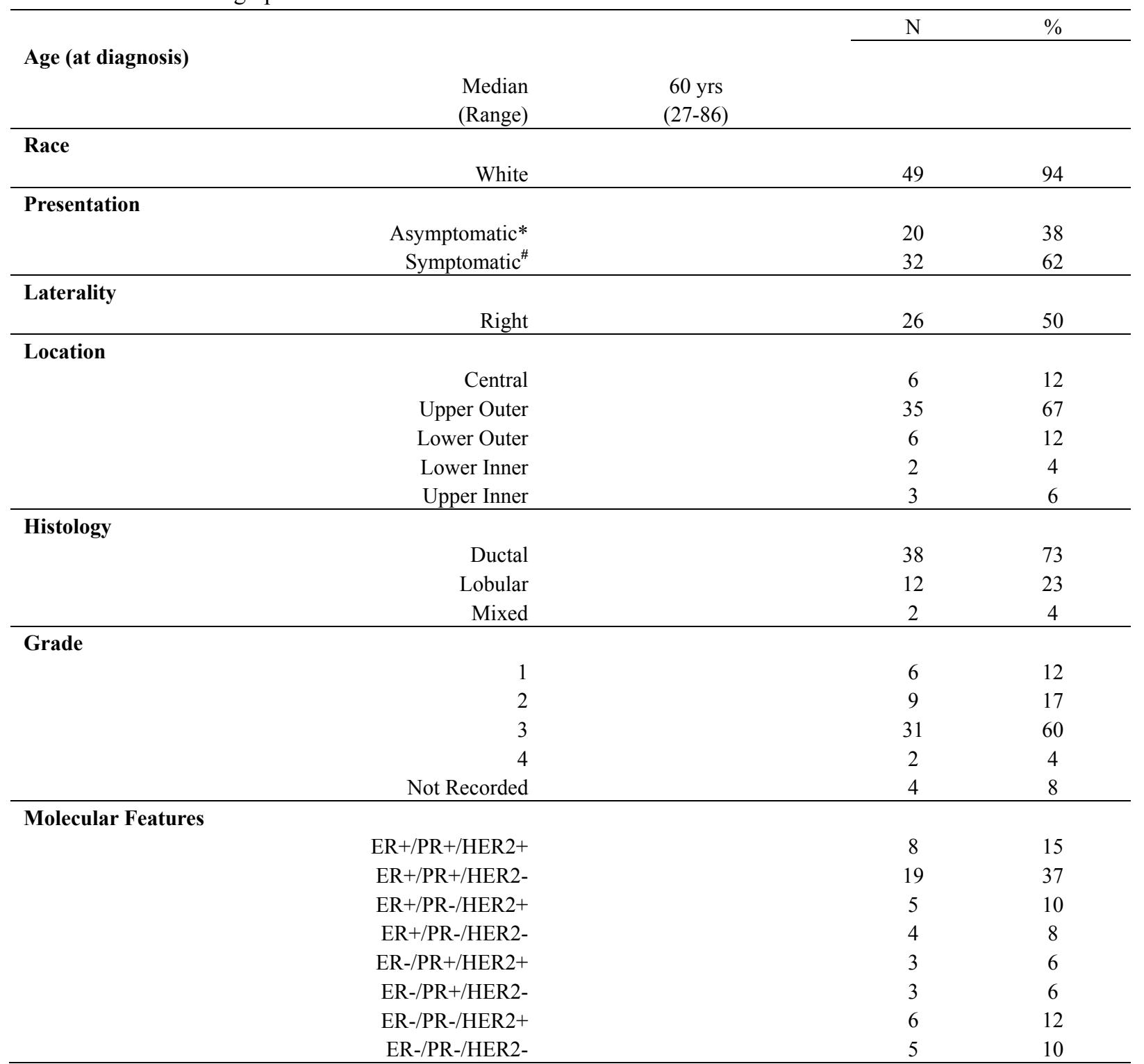

\footnotetext{
*Includes 19 patients detected on screening mammography and 1 patient incidental on positron emission tomography.
}

"Includes 31 patients detected by self-palpation and 1 patient with nipple discharge without palpable mass. 
Table 2. Surgical-, Pathology-, and Treatment-Related Data

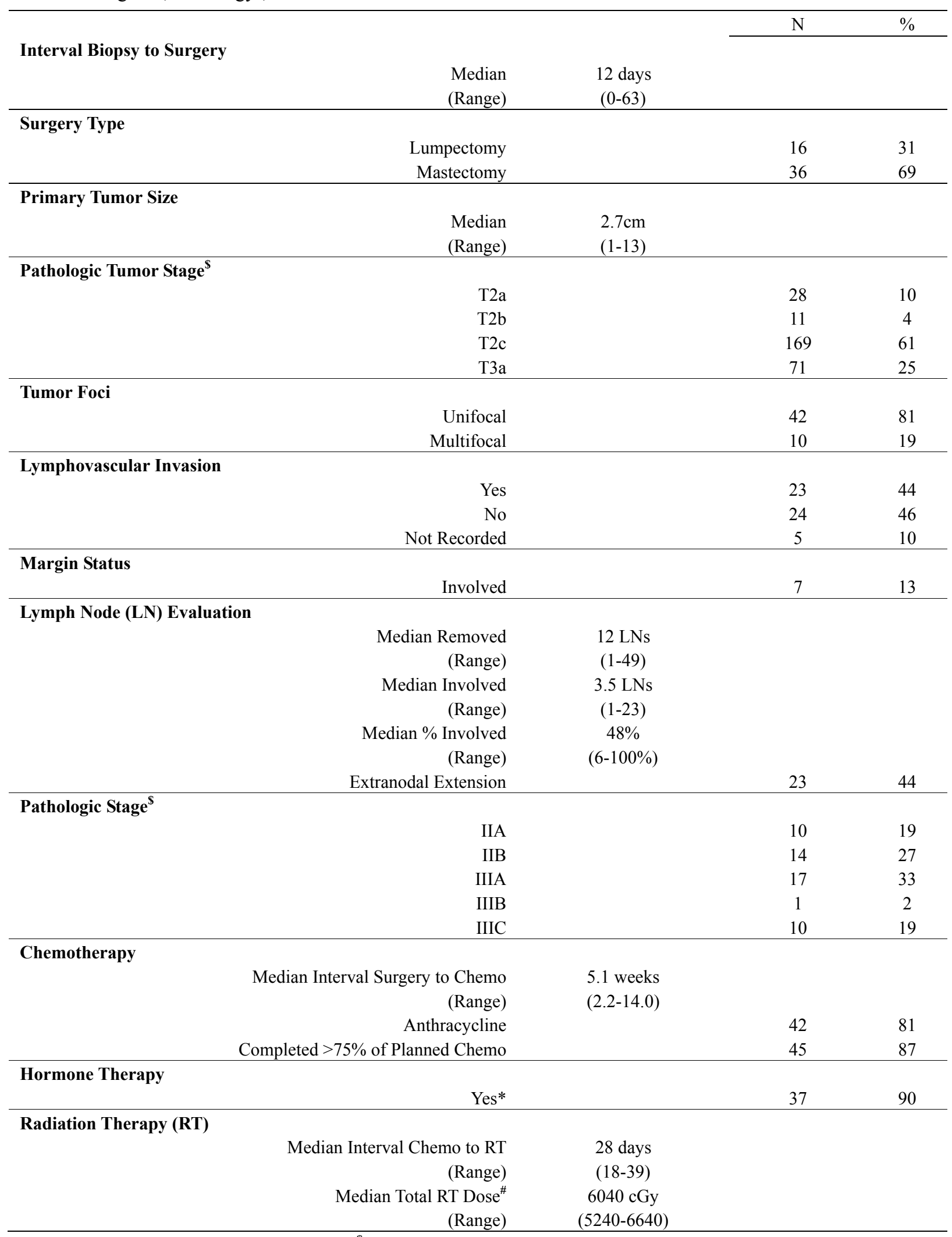

*Excludes 11 hormone-insensitive patients. ${ }^{\$}$ American Joint Committee on Cancer, TNM Staging Manual, version 7.0.

${ }^{\#}$ Inclusive of breast/chestwall dose plus boost, when employed. 
At a median follow-up of 77.2 months (range 19.9-119.4, with $85 \%$ followed $\geq 5$ years), 8 patients had experienced disease recurrence at a median of 49.9 months (14.8-87.7). Patterns of failure included distant-only in 6 patients and locoregional plus distant in 2 patients. Seven patients had died; 3 with recurrent disease, 3 of other cause (1 each of myocardial infarction, end stage renal disease, and acute myelogenous leukemia; all were without recurrent disease at last follow-up), and 1 of unknown cause (probable myocardial infarction, without evidence of disease recurrence 14 months prior). Analysis of factors associated with freedom from failure demonstrated a statistically significant association with number of lymph nodes involved, while absolute weight change and BMI at 1, 3, and 4 years post-chemotherapy completion was associated with overall survival (Table 3; comprehensive analysis in Appendix A).

Table 3. Univariate analyses of factors associated with disease control and survival

\begin{tabular}{|c|c|c|c|c|c|c|}
\hline & & & \multicolumn{2}{|c|}{ Disease Control } & \multicolumn{2}{|c|}{ Overall Survival } \\
\hline & & & $\begin{array}{c}\exp (\mathrm{b}) \\
(95 \% \mathrm{CI})\end{array}$ & $\mathrm{p}$-value & $\begin{array}{c}\exp (\mathrm{b}) \\
(95 \% \mathrm{CI})\end{array}$ & p-value \\
\hline Number of LNs Involved & & & $\begin{array}{c}1.119 \\
(1.026-1.221)\end{array}$ & 0.011 & $\begin{array}{c}1.051 \\
(0.945-1.168)\end{array}$ & 0.358 \\
\hline$\%$ of LNs Involved & & & $\begin{array}{c}10.404 \\
(0.983-110.128) \\
\end{array}$ & 0.052 & $\begin{array}{c}1.555 \\
(0.157-15.420) \\
\end{array}$ & 0.706 \\
\hline $\begin{array}{l}\text { Absolute Change Weight } \\
\text { Post-Op/Pre-Chemo to } \\
\text { Post-Chemo }\end{array}$ & 1 & year & $\begin{array}{c}1.008 \\
(0.947-1.072)\end{array}$ & 0.803 & $\begin{array}{c}0.956 \\
(0.918-0.995)\end{array}$ & 0.026 \\
\hline $\begin{array}{l}\text { Absolute Change BMI } \\
\text { Post-Op/Pre-Chemo to } \\
\text { Post-Chemo }\end{array}$ & 1 & year & $\begin{array}{c}1.044 \\
(0.725-1.504)\end{array}$ & 0.817 & $\begin{array}{c}0.770 \\
(0.609-0.974)\end{array}$ & 0.029 \\
\hline $\begin{array}{l}\text { Absolute Change Weight } \\
\text { Post-Op/Pre-Chemo to } \\
\text { Post-Chemo }\end{array}$ & 2 & years & $\begin{array}{c}0.990 \\
(0.938-1.046)\end{array}$ & 0.730 & $\begin{array}{c}0.934 \\
(0.863-1.011)\end{array}$ & 0.093 \\
\hline $\begin{array}{l}\text { Absolute Change BMI } \\
\text { Post-Op/Pre-Chemo to } \\
\text { Post-Chemo }\end{array}$ & 2 & years & $\begin{array}{c}0.959 \\
(0.697-1.320)\end{array}$ & 0.798 & $\begin{array}{c}0.669 \\
(0.417-1.076)\end{array}$ & 0.097 \\
\hline $\begin{array}{l}\text { Absolute Change Weight } \\
\text { Post-Op/Pre-Chemo to } \\
\text { Post-Chemo }\end{array}$ & 3 & years & $\begin{array}{c}0.962 \\
(0.910-1.017)\end{array}$ & 0.169 & $\begin{array}{c}0.887 \\
(0.812-0.969)\end{array}$ & 0.008 \\
\hline $\begin{array}{l}\text { Absolute Change BMI } \\
\text { Post-Op/Pre-Chemo to } \\
\text { Post-Chemo }\end{array}$ & 3 & years & $\begin{array}{c}0.797 \\
(0.575-1.105)\end{array}$ & 0.173 & $\begin{array}{c}0.501 \\
(0.303-0.830)\end{array}$ & 0.007 \\
\hline $\begin{array}{l}\text { Absolute Change Weight } \\
\text { Post-Op/Pre-Chemo to } \\
\text { Post-Chemo }\end{array}$ & 4 & years & $\begin{array}{c}0.953 \\
(0.876-1.035)\end{array}$ & 0.254 & $\begin{array}{c}0.869 \\
(0.781-0.966)\end{array}$ & 0.009 \\
\hline $\begin{array}{l}\text { Absolute Change BMI } \\
\text { Post-Op/Pre-Chemo to } \\
\text { Post-Chemo }\end{array}$ & 4 & years & $\begin{array}{c}0.741 \\
(0.455-1.209)\end{array}$ & 0.230 & $\begin{array}{c}0.448 \\
(0.248-0.810)\end{array}$ & 0.008 \\
\hline
\end{tabular}

With respect to weight change during and after chemotherapy, these specific data are demonstrated in Table 4. 
Table 4. Weight and Body Mass Index (BMI) change during and after chemotherapy

\begin{tabular}{|c|c|c|c|}
\hline \multirow{2}{*}{$\begin{array}{c}\text { Interval } \\
\text { Post-Chemotherapy } \\
\text { (n) }\end{array}$} & Weight Change & BMI Change & Relative Change \\
\hline & $\begin{array}{l}\text { Median } \\
\text { (Range) }\end{array}$ & Median (Range) & $\begin{array}{l}\text { Median } \\
\text { (Range) }\end{array}$ \\
\hline $\begin{array}{r}\text { Immediate } \\
(52)\end{array}$ & $\begin{array}{c}-1.9 \mathrm{lbs} \\
(-41.0 \text { to }+24.8)\end{array}$ & $\begin{array}{c}-0.4 \mathrm{~cm} / \mathrm{m}^{2} \\
(-7.0 \text { to }+4.1)\end{array}$ & $\begin{array}{c}-1.3 \% \\
(-18.1 \text { to }+14.1)\end{array}$ \\
\hline $\begin{array}{r}\text { 6-month } \\
(52)\end{array}$ & $\begin{array}{c}+2.4 \mathrm{lbs} \\
(-54.0 \text { to }+33.6)\end{array}$ & $\begin{array}{l}+0.4 \mathrm{~cm} / \mathrm{m}^{2} \\
(-9.3 \text { to }+6.1)\end{array}$ & $\begin{array}{c}+1.3 \% \\
(-18.4 \text { to } 21.5)\end{array}$ \\
\hline $\begin{array}{r}1-y e a r \\
(52)\end{array}$ & $\begin{array}{c}+4.5 \mathrm{lbs} \\
(-54.0 \text { to }+30.0)\end{array}$ & $\begin{array}{c}+0.8 \mathrm{~cm} / \mathrm{m}^{2} \\
(-9.3 \text { to }+4.8)\end{array}$ & $\begin{array}{c}+2.4 \% \\
(-18.4 \text { to }+15.0)\end{array}$ \\
\hline $\begin{array}{r}\text { 2-year } \\
(49)\end{array}$ & $\begin{array}{c}+3.0 \mathrm{lbs} \\
(-27.0 \text { to }+47.0)\end{array}$ & $\begin{array}{l}+0.7 \mathrm{~cm} / \mathrm{m}^{2} \\
(-4.5 \text { to }+7.5)\end{array}$ & $\begin{array}{c}+2.7 \% \\
(-15.4 \text { to }+23.3)\end{array}$ \\
\hline $\begin{array}{r}3 \text {-year } \\
(48)\end{array}$ & $\begin{array}{c}+3.5 \mathrm{lbs} \\
(-46.0 \text { to }+33.0)\end{array}$ & $\begin{array}{c}+0.7 \mathrm{~cm} / \mathrm{m}^{2} \\
(-7.9 \text { to }+5.7)\end{array}$ & $\begin{array}{c}+2.5 \% \\
(-15.6 \text { to }+18.8)\end{array}$ \\
\hline $\begin{array}{r}\text { 4-year } \\
(44)\end{array}$ & $\begin{array}{c}+1.0 \mathrm{lbs} \\
(-62.0 \text { to }+33.0)\end{array}$ & $\begin{array}{c}+0.2 \mathrm{~cm} / \mathrm{m}^{2} \\
(-10.6 \text { to }+6.1)\end{array}$ & $\begin{array}{c}+0.8 \% \\
(-21.1 \text { to }+23.7)\end{array}$ \\
\hline $\begin{array}{r}5 \text {-year } \\
(39) \\
\end{array}$ & $\begin{array}{c}+5.0 \mathrm{lbs} \\
(-41.0 \text { to }+45.0)\end{array}$ & $\begin{array}{c}+0.8 \mathrm{~cm} / \mathrm{m}^{2} \\
(-6.4 \text { to }+7.8)\end{array}$ & $\begin{array}{c}+3.5 \% \\
(-19.4 \text { to } 33.2) \\
\end{array}$ \\
\hline
\end{tabular}

\section{Discussion}

The purpose of the present investigation is to determine the impact of weight change during chemotherapy on breast cancer control within a high-risk population of women with node-positive breast cancer who underwent tri-modality therapy, including surgery, chemotherapy, and radiation. Similar to several previously-published studies, we observed that weight gain is a common problem in patients receiving adjuvant chemotherapy (Demark-Wahnefried et al., 1997; Demark-Wahnefried, Winer, \& Rimer, 1993; Ganz et al., 1987; Goodwin et al., 1999; Heasman et al., 1985). Obesity is a known risk factor for the development of new cases of breast cancer and has been associated with decreased survival in active breast cancer patients (Protani et al., 2010). A prevailing hypothesis for this is that obese individuals have elevated serum estrogen levels, which has consistently been positively correlated with increased risk for development of breast cancer (Key et al., 2002). Other proposed mechanisms that may link obesity to cancer susceptibility include: diet (caloric excess and positive energy balance), sedentary lifestyle, hyperinsulinemia, insulin-like growth factors (IGF), IGF binding proteins (anabolic and anti-apoptotic effects), increased production of pro-inflammatory molecules (Interleukin-6, adiponectin, and Tumor Necrosis Factor-a), oxidative stress, increased angiogenesis, and obesity-induced hypoxia (De Pergola \& Silvestris, 2013).

Specific to recurrence risk in patients with breast cancer, several previously-published studies have investigated the correlation of obesity with outcome. For example, Sparano et al. retrospectively analyzed data from three Eastern Cooperative Oncology Group (ECOG) trials, including approximately 7,000 node-positive and high-risk node-negative patients treated with anthracycline-based chemotherapy (and endocrine therapy, for hormone-sensitive tumors). A strong association was identified between obesity and disease recurrence in hormone-sensitive/HER-2 negative disease, despite adjusting for covariates including age, race, menopausal status, tumor size, number of positive axillary lymph nodes, and type of surgery (Sparano et al., 2012).

Specific to all-cause mortality within a cancer patient population, obesity at diagnosis is inversely associated with overall survival. Dignam et al. (2006) demonstrated higher BMI to be associated with greater overall mortality within a hormone-insensitive, node-negative breast cancer patient population. This was most pronounced in patients with a BMI $>35$, who were noted to have a two-fold increased risk of non-cancer death, most commonly due to chronic disease. Interestingly, increasing BMI was also associated with secondary primary cancers, excluding the contralateral breast. Specific to our own study population of high-risk, node-positive breast cancer patients treated with uniform contemporary guideline-based management, we did not identify any baseline weight or BMI characteristics which proved predictive of cancer recurrence or survival. One possibility is that the uniformity of treatment, employing optimal locoregional and systemic therapies, has decreased recurrence rates (and thus mortality) such that baseline obesity (or BMI) are no longer stand-alone risk factors. A second possibility is that the pattern of failure in the era of prolonged therapy may be pushed forward, and 10-15 year follow-up may be required to adequately assess these endpoints. For example, The Early Breast Cancer Trialists' Collaborative Group meta-analysis revealed that tamoxifen had a "carry-over effect" of at least 
5 years after the completion of 5 years of therapy. Consequently, women who have completed adjuvant tamoxifen are at a significantly lower risk of breast cancer recurrence or death than women who do not receive tamoxifen for up to ten years after surgery (Early Breast Cancer Trialists' Group, 2005). Finally, a third possibility is that the increased risk of recurrence or mortality posed by obesity may be sufficiently small that a larger patient population may be required to detect such risk.

A unique contribution of the present study has been the longitudinal recording of patient weight and BMI before and at several points after chemotherapy. While our primary hypothesis that weight change during chemotherapy would prove to be associated with disease control or survival outcomes did not prove correct, we did identify an increase in all-cause mortality in association with the degree of absolute weight change at specific time points following chemotherapy completion. Absolute weight loss and BMI decreases at years 1, 3, and 4 post-chemotherapy were associated with mortality. As our non-breast cancer causes of death included acute myelogenous leukemia, end-stage renal disease, dementia, and an unknown cause in a patient with chronic diabetes mellitus, we suspect that the weight loss was primarily related to these processes rather than truly independently predictive. Similarly, Adams, Leitzmann, and Ballard-Barbash (2013) observed an increase in mortality risk in those 50-69 years of age who lost weight $>0.2 \mathrm{~kg}$ per year, particularly in those who rated their health as fair or poor. Within the current study, the median age at diagnosis was 60 , with variable baseline health status, such that comorbid conditions were likely to have had a greater impact on the weight change association with mortality independent of treatment and/or recurrence. It is interesting to note that despite the intensity of contemporary multiagent breast cancer-specific chemotherapy, neither weight/BMI changes during nor immediately following chemotherapy were associated with survival, only changes years later. This would suggest potential changes in the severity of the comorbid condition, rather than effects of chemotherapy, though late effects of cytotoxic chemotherapy (e.g., leukemia) certainly cannot be overlooked (Dong \& Chen, 2014).

In addition to the post-chemotherapy weight changes, the number of lymph nodes involved was significantly associated with disease control. This has long been demonstrated as perhaps the most important prognostic indicator for disease free survival (Elkhodary et al., 2014; Wiznia et al., 2014; Singletary et al., 2002). More recently, the lymph node ratio (LNR; number of positive lymph nodes divided by the total examined) has been shown to be an alternative means of assessing risk of disease free survival, with some superiority when fewer than 10 lymph nodes are identified within the dissection specimen (Elkhodary et al., 2014; Wiznia et al., 2014; Chagpar, Camp, \& Rimm, 2011). While our series did not meet the threshold for statistical significance for LNR association with disease control $(\mathrm{p}=0.052)$, this may have been due to the low number of cancer recurrence events.

In conclusion, the present investigation did not detect statistically significant associations between weight or BMI change during chemotherapy and disease control or survival. Subsequent decreases in weight or BMI were associated with increased mortality, most commonly from non-breast-cancer causes, though the interaction of treatment with subsequent development and/or severity of comorbid conditions cannot be entirely ruled out. We did not detect a correlation between baseline weight and BMI with breast cancer recurrence or death, noting that despite the high-risk (node-positive) patient population, disease control and survival outcomes at 5 years were favorable. Longer follow-up is required to determine whether baseline weight or BMI (and/or changes during chemotherapy) may have a measurable impact at later time points.

\section{Acknowledgments}

No funding support was received in the design, conduct, or manuscript development process of this study. All three lead authors contributed equally to the design, data extraction, and manuscript development process of this study.

\section{References}

Adams, K. F., Leitzmann, M. F., Ballard-Barbash, R., Albanes, D., Harris, T. B., Hollenbeck, A., \& Kipnis, V. (2013). Body mass and weight change in adults in relation to mortality risk. American journal of epidemiology, kwt254. PMid:24173550. http://dx.doi.org/10.1093/aje/kwt254

Camoriano, J. K., Loprinzi, C. L., Ingle, J. N., Therneau, T. M., Krook, J. E., \& Veeder, M. H. (1990). Weight change in women treated with adjuvant therapy or observed following mastectomy for node-positive breast cancer. PMid:2199619. Journal of Clinical Oncology, 8(8), 1327-1334.

Chagpar, A. B., Camp, R. L., \& Rimm, D. L. (2011). Lymph node ratio should be considered for incorporation into staging for breast cancer. Annals of surgical oncology, 18(11), 3143-3148. http://dx.doi.org/10.1245/s10434-011-2012-9 
Chlebowski, R. T., Aiello, E., \& McTiernan, A. (2002). Weight loss in breast cancer patient management. PMid:11844838. Journal of clinical oncology, 20(4), 1128-1143. http://dx.doi.org/10.1200/JCO.20.4.1128

CTSU, R. I. (2005). Effects of chemotherapy and hormonal therapy for early breast cancer on recurrence and 15-year survival: an overview of the randomised trials. Lancet, 365, 1687-1717. http://dx.doi.org/10.1016/S0140-6736(05)66544-0

De Pergola, G., \& Silvestris, F. (2013). Obesity as a major risk factor for cancer. Journal of obesity, 2013. http://dx.doi.org/10.1155/2013/291546

Demark-Wahnefried, W., Peterson, B. L., Winer, E. P., Marks, L., Aziz, N., Marcom, P. K., ... \& Rimer, B. K. (2001). Changes in weight, body composition, and factors influencing energy balance among premenopausal breast cancer patients receiving adjuvant chemotherapy. Journal of clinical oncology, 19(9), 2381-2389. PMid:11331316.

Demark-Wahnefried, W., Winer, E. P., \& Rimer, B. K. (1993). Why women gain weight with adjuvant chemotherapy for breast cancer. PMid:8315439. Journal of Clinical Oncology, 11(7), 1418-1429.

Dignam, J. J., Wieand, K., Johnson, K. A., Raich, P., Anderson, S. J., Somkin, C., \& Wickerham, D. L. (2006). Effects of obesity and race on prognosis in lymph node-negative, estrogen receptor-negative breast cancer. Breast cancer research and treatment, 97(3), 245-254. PMid:16331345. http://dx.doi.org/10.1007/s10549-005-9118-3

Dixon, J. K., Moritz, D. A., \& Baker, F. L. (1978, July). Breast cancer and weight gain: an unexpected finding. In Oncology nursing forum (Vol. 5, No. 3, pp. 5-7). PMid:248815.

Dong, C., \& Chen, L. (2014). Second malignancies after breast cancer: The impact of adjuvant therapy. Molecular and clinical oncology, 2(3), 331.

Edge, S. B., \& Compton, C. C. (2010). The American Joint Committee on Cancer: the 7th edition of the AJCC cancer staging manual and the future of TNM. Annals of surgical oncology, 17(6), 1471-1474.

Elkhodary, T. R., Ebrahim, M. A., Hatata, E. E., \& Niazy, N. A. (2014). Prognostic value of lymph node ratio in the node-positive breast cancer in Egyptian patients. $J$ Egypt Nat Cancer Ins, 26, 31-35. http://dx.doi.org/10.1016/j.jnci.2013.10.001

Ganz, P. A., Schag, C. C., Polinsky, M. L., Heinrich, R. L., \& Flack, V. F. (1987). Rehabilitation needs and breast cancer: the first month after primary therapy. Breast cancer research and treatment, 10(3), $243-253$. PMid:3447644. http://dx.doi.org/10.1007/BF01805761

Goodwin, P. J., Ennis, M., Pritchard, K. I., McCready, D., Koo, J., Sidlofsky, S., ... \& Redwood, S. (1999). Adjuvant treatment and onset of menopause predict weight gain after breast cancer diagnosis. PMid:10458225. Journal of Clinical Oncology, 17(1), 120-120.

Heasman, K. Z., Sutherland, H. J., Campbell, J. A., Elhakim, T., \& Boyd, N. F. (1985). Weight gain during adjuvant chemotherapy for breast cancer. Breast cancer research and treatment, 5(2), 195-200. http://dx.doi.org/10.1007/BF01805994

Key, T., Appleby, P., Barnes, I., \& Reeves, G. (2002). Endogenous sex hormones and breast cancer in postmenopausal women: reanalysis of nine prospective studies. Journal of the National Cancer Institute, 94(8), 606-616. PMid:11959894. http://dx.doi.org/10.1093/jnci/94.8.606

Newman, L. A. (2009, October). Epidemiology of locally advanced breast cancer. In Seminars in radiation oncology (Vol. 19, No. 4, pp. 195-203). WB Saunders. http://dx.doi.org/10.1016/j.semradonc.2009.05.003

Protani, M., Coory, M., \& Martin, J. H. (2010). Effect of obesity on survival of women with breast cancer: systematic review and meta-analysis. Breast cancer research and treatment, 123(3), 627-635. PMid:20571870. http://dx.doi.org/10.1007/s10549-010-0990-0

Siegel, R., Naishadham, D., \& Jemal, A. (2013). Cancer statistics, 2013. CA: a cancer journal for clinicians, 63(1), 11-30. http://dx.doi.org/10.3322/caac.21166

Singletary, S. E., Allred, C., Ashley, P., Bassett, L. W., Berry, D., Bland, K. I., ... \& Greene, F. L. (2002). Revision of the American Joint Committee on Cancer staging system for breast cancer. Journal of clinical oncology, 20(17), 3628-3636. http://dx.doi.org/10.1200/JCO.2002.02.026 PMid:12202663

Sparano, J. A., Wang, M., Zhao, F., Stearns, V., Martino, S., Ligibel, J. A., ... \& Davidson, N. E. (2012). Obesity at diagnosis is associated with inferior outcomes in hormone receptor - positive operable breast 
cancer. Cancer, 118(23), 5937-5946. http://dx.doi.org/10.1002/cncr.27527

Surveillance, Epidemiology, and End Results (SEER) Program. SEER*Stat Database: Incidence-SEER 18 Regs Public Use, Nov. 2011 Sub (2000-2009)-Linked to County Attributes-Total US, 1969-2009 Counties. Bethesda, MD: National Cancer Institute, Division of Cancer Control and Population Sciences, Surveillance Research Program, Cancer Statistics Branch; 2012.

Wahnefried, W., Rimer, B. K., \& Winer, E. P. (1997). Weight gain in women diagnosed with breast cancer. Journal of the American Dietetic Association, 97(5), 519-529. http://dx.doi.org/10.1002/cncr.27466

Wiznia, L. E., Lannin, D. R., Evans, S. B., Hofstatter, E. W., Horowitz, N. R., Killelea, B. K., ... \& Chagpar, A. B. (2014). The Number of Lymph Nodes Dissected in Breast Cancer Patients Influences the Accuracy of Prognosis.Annals of surgical oncology, 21(2), 389-394. http://dx.doi.org/10.1245/s10434-013-3308-8

\section{Appendix A}

Supplement to Table 3. Univariate Analyses of Factors Associated with Disease Control and Survival.

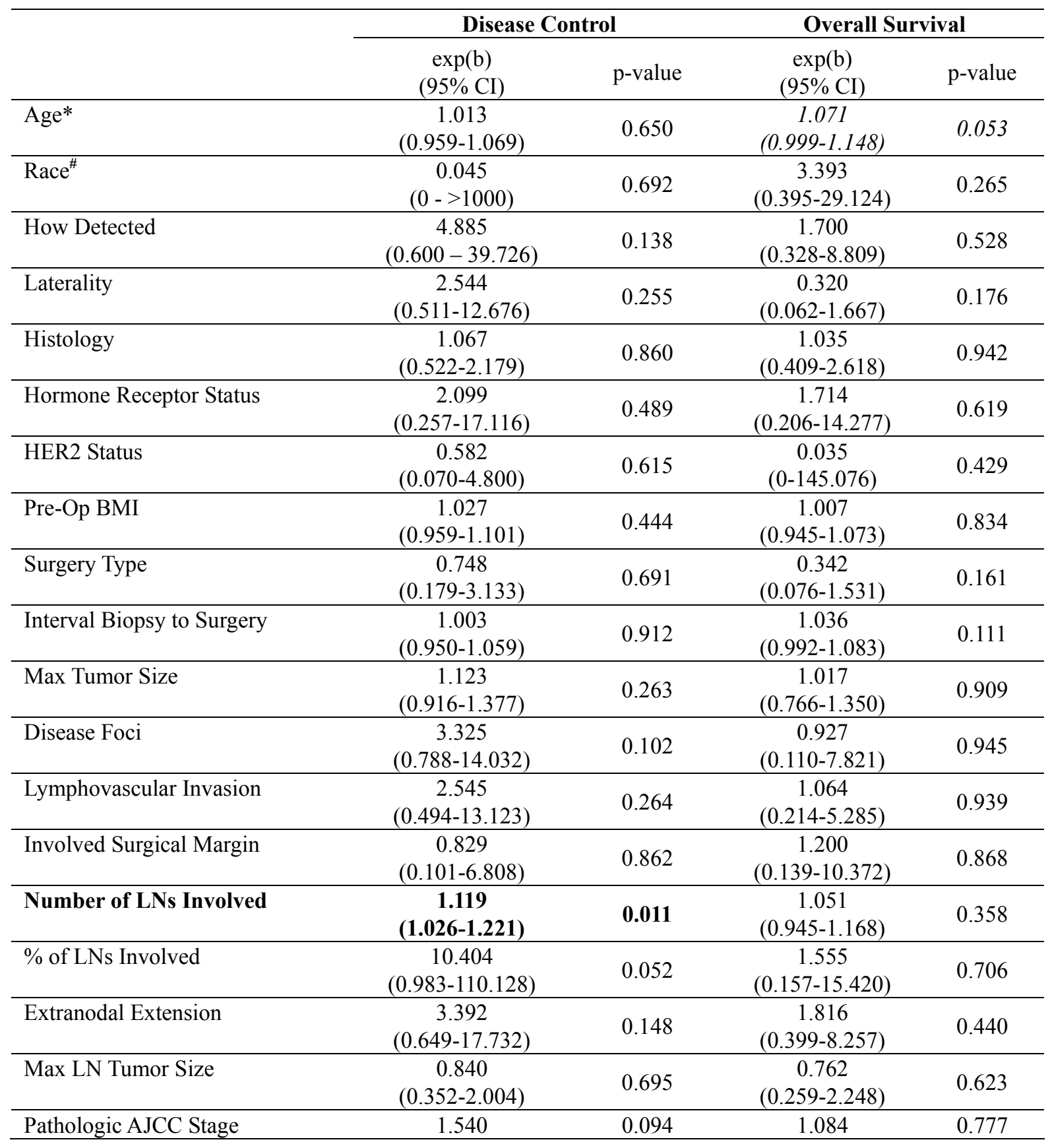




\begin{tabular}{|c|c|c|c|c|}
\hline & $(0.929-2.552)$ & & $(0.622-1.887)$ & \\
\hline Post-Op/Pre-Chemo BMI & $\begin{array}{c}0.983 \\
(0.878-1.102)\end{array}$ & 0.774 & $\begin{array}{c}1.045 \\
(0.938-1.165)\end{array}$ & 0.422 \\
\hline $\begin{array}{l}\text { Absolute Change Weight } \\
\text { Pre-Op to Post-Op/Pre-Chemo }\end{array}$ & $\begin{array}{c}1.039 \\
(0.895-1.207) \\
\end{array}$ & 0.611 & $\begin{array}{c}1.033 \\
(0.872-1.224) \\
\end{array}$ & 0.708 \\
\hline $\begin{array}{l}\text { Absolute Change BMI } \\
\text { Pre-Op to Post-Op/Pre-Chemo }\end{array}$ & $\begin{array}{c}1.246 \\
(0.529-2.936)\end{array}$ & 0.615 & $\begin{array}{c}1.164 \\
(0.446-3.037)\end{array}$ & 0.756 \\
\hline Anthracycline & $\begin{array}{c}0.383 \\
(0.091-1.605) \\
\end{array}$ & 0.189 & $\begin{array}{c}0.592 \\
(0.114-3.060)\end{array}$ & 0.531 \\
\hline Completed $>75 \%$ Chemo & $\begin{array}{c}1.042 \\
(0.128-8.479)\end{array}$ & 0.969 & $\begin{array}{c}0.351 \\
(0.068-1.824)\end{array}$ & 0.213 \\
\hline $\begin{array}{l}\text { Interval Mastectomy to Adjuvant } \\
\text { Chemotherapy }\end{array}$ & $\begin{array}{c}0.950 \\
(0.680-1.328)\end{array}$ & 0.765 & $\begin{array}{c}1.225 \\
(0.942-1.592)\end{array}$ & 0.129 \\
\hline $\begin{array}{l}\text { Interval Adjuvant Chemotherapy } \\
\text { Start to Finish }\end{array}$ & $\begin{array}{c}0.996 \\
(0.978-1.015)\end{array}$ & 0.627 & $\begin{array}{c}0.990 \\
(0.971-1.009)\end{array}$ & 0.290 \\
\hline Post-Chemotherapy BMI & $\begin{array}{c}1.000 \\
(0.892-1.121)\end{array}$ & 0.995 & $\begin{array}{c}1.027 \\
(0.912-1.155)\end{array}$ & 0.663 \\
\hline $\begin{array}{l}\text { Absolute Change Weight } \\
\text { Post-Op/Pre-Chemo to Immediate } \\
\text { Post-Chemo }\end{array}$ & $\begin{array}{c}1.039 \\
(0.970-1.112)\end{array}$ & 0.274 & $\begin{array}{c}0.952 \\
(0.895-1.013)\end{array}$ & 0.123 \\
\hline $\begin{array}{l}\text { Absolute Change BMI } \\
\text { Post-Op/Pre-Chemo to Immediate } \\
\text { Post-Chemo }\end{array}$ & $\begin{array}{c}1.248 \\
(0.830-1.879)\end{array}$ & 0.287 & $\begin{array}{c}0.758 \\
(0.524-1.099)\end{array}$ & 0.144 \\
\hline BMI at 6 months Post-Chemo & $\begin{array}{c}1.012 \\
(0.904-1.133) \\
\end{array}$ & 0.834 & $\begin{array}{c}1.036 \\
(0.920-1.167) \\
\end{array}$ & 0.561 \\
\hline $\begin{array}{l}\text { Absolute Change Weight } \\
\text { Post-Op/Pre-Chemo to 6-month } \\
\text { Post-Chemo }\end{array}$ & $\begin{array}{c}1.065 \\
(0.985-1.150)\end{array}$ & 0.112 & $\begin{array}{c}0.978 \\
(0.930-1.029)\end{array}$ & 0.390 \\
\hline $\begin{array}{l}\text { Absolute Change BMI } \\
\text { Post-Op/Pre-Chemo to 6-month } \\
\text { Post-Chemo }\end{array}$ & $\begin{array}{c}1.472 \\
(0.932-2.323)\end{array}$ & 0.097 & $\begin{array}{c}0.890 \\
(0.657-1.204)\end{array}$ & 0.449 \\
\hline BMI at 1 year Post-Chemo & $\begin{array}{c}0.988 \\
(0.883-1.105)\end{array}$ & 0.829 & $\begin{array}{c}1.007 \\
(0.896-1.133)\end{array}$ & 0.901 \\
\hline $\begin{array}{l}\text { Absolute Change Weight } \\
\text { Post-Op/Pre-Chemo to } 1 \text { year } \\
\text { Post-Chemo }\end{array}$ & $\begin{array}{c}1.008 \\
(0.947-1.072)\end{array}$ & 0.803 & $\begin{array}{c}0.956 \\
(0.918-0.995)\end{array}$ & 0.026 \\
\hline $\begin{array}{l}\text { Absolute Change BMI } \\
\text { Post-Op/Pre-Chemo to } 1 \text { year } \\
\text { Post-Chemo }\end{array}$ & $\begin{array}{c}1.044 \\
(0.725-1.504)\end{array}$ & 0.817 & $\begin{array}{c}0.770 \\
(0.609-0.974)\end{array}$ & 0.029 \\
\hline BMI at 2 years Post-Chemo & $\begin{array}{c}0.935 \\
(0.814-1.074) \\
\end{array}$ & 0.341 & $\begin{array}{c}0.948 \\
(0.803-1.118) \\
\end{array}$ & 0.525 \\
\hline $\begin{array}{l}\text { Absolute Change Weight } \\
\text { Post-Op/Pre-Chemo to } 2 \text { years } \\
\text { Post-Chemo }\end{array}$ & $\begin{array}{c}0.990 \\
(0.938-1.046)\end{array}$ & 0.730 & $\begin{array}{c}0.934 \\
(0.863-1.011)\end{array}$ & 0.093 \\
\hline $\begin{array}{l}\text { Absolute Change BMI } \\
\text { Post-Op/Pre-Chemo to } 2 \text { years } \\
\text { Post-Chemo }\end{array}$ & $\begin{array}{c}0.959 \\
(0.697-1.320)\end{array}$ & 0.798 & $\begin{array}{c}0.669 \\
(0.417-1.076)\end{array}$ & 0.097 \\
\hline BMI at 3 years Post-Chemo & $\begin{array}{c}0.902 \\
(0.776-1.048) \\
\end{array}$ & 0.177 & $\begin{array}{c}0.900 \\
(0.749-1.081) \\
\end{array}$ & 0.260 \\
\hline $\begin{array}{l}\text { Absolute Change Weight } \\
\text { Post-Op/Pre-Chemo to } 3 \text { years } \\
\text { Post-Chemo }\end{array}$ & $\begin{array}{c}0.962 \\
(0.910-1.017)\end{array}$ & 0.169 & $\begin{array}{c}0.887 \\
(0.812-0.969)\end{array}$ & 0.008 \\
\hline $\begin{array}{l}\text { Absolute Change BMI } \\
\text { Post-Op/Pre-Chemo to } 3 \text { years } \\
\text { Post-Chemo }\end{array}$ & $\begin{array}{c}0.797 \\
(0.575-1.105) \\
\end{array}$ & 0.173 & $\begin{array}{c}0.501 \\
(\mathbf{0 . 3 0 3 - 0 . 8 3 0 )}\end{array}$ & 0.007 \\
\hline
\end{tabular}




\begin{tabular}{|c|c|c|c|c|}
\hline BMI at 4 years Post-Chemo & $\begin{array}{c}0.924 \\
(0.775-1.102) \\
\end{array}$ & 0.380 & $\begin{array}{c}0.950 \\
(0.787-1.147) \\
\end{array}$ & 0.595 \\
\hline $\begin{array}{l}\text { Absolute Change Weight } \\
\text { Post-Op/Pre-Chemo to } 4 \text { years } \\
\text { Post-Chemo }\end{array}$ & $\begin{array}{c}0.953 \\
(0.876-1.035)\end{array}$ & 0.254 & $\begin{array}{c}0.869 \\
(0.781-0.966)\end{array}$ & 0.009 \\
\hline $\begin{array}{l}\text { Absolute Change BMI } \\
\text { Post-Op/Pre-Chemo to } 4 \text { years } \\
\text { Post-Chemo }\end{array}$ & $\begin{array}{c}0.741 \\
(0.455-1.209)\end{array}$ & 0.230 & $\begin{array}{c}0.448 \\
(0.248-0.810)\end{array}$ & 0.008 \\
\hline BMI at 5 years Post-Chemo & $\begin{array}{c}0.950 \\
(0.789-1.145) \\
\end{array}$ & 0.592 & $\begin{array}{c}0.942 \\
(0.749-1.185) \\
\end{array}$ & 0.611 \\
\hline $\begin{array}{l}\text { Absolute Change Weight } \\
\text { Post-Op/Pre-Chemo to } 5 \text { years } \\
\text { Post-Chemo }\end{array}$ & $\begin{array}{c}0.974 \\
(0.913-1.040)\end{array}$ & 0.431 & $\begin{array}{c}0.863 \\
(0.713-1.044)\end{array}$ & 0.128 \\
\hline $\begin{array}{l}\text { Absolute Change BMI } \\
\text { Post-Op/Pre-Chemo to } 5 \text { years } \\
\text { Post-Chemo }\end{array}$ & $\begin{array}{c}0.833 \\
(0.561-1.238)\end{array}$ & 0.367 & $\begin{array}{c}0.242 \\
(0.004-13.283)\end{array}$ & 0.487 \\
\hline Hormone Therapy $\$$ & $\begin{array}{c}0.530 \\
(0.063-4.446) \\
\end{array}$ & 0.559 & $\begin{array}{c}0.477 \\
(0.055-4.134)\end{array}$ & 0.502 \\
\hline Interval Surgery to Radiotherapy & $\begin{array}{c}0.959 \\
(0.837-1.099) \\
\end{array}$ & 0.547 & $\begin{array}{c}0.981 \\
(0.851-1.132) \\
\end{array}$ & 0.798 \\
\hline Interval Chemo to Radiotherapy & $\begin{array}{c}0.997 \\
(0.952-1.043) \\
\end{array}$ & 0.892 & $\begin{array}{c}1.007 \\
(0.971-1.045) \\
\end{array}$ & 0.696 \\
\hline
\end{tabular}

*Continuous variable; "Categorical variable. ${ }^{\$}$ Excludes 11 hormone-insensitive patients, for whom hormone therapy was not indicated.

\section{Copyrights}

Copyright for this article is retained by the author(s), with first publication rights granted to the journal.

This is an open-access article distributed under the terms and conditions of the Creative Commons Attribution license (http://creativecommons.org/licenses/by/3.0/). 